\title{
BASIC COMPONENTS OF GLUTATHION SYSTEM IN RAT ERYTHROCYTES UNDER CONDITIONS OF TOXIC DAMAGE ON THE BACKGROUND OF AN ALIMENTAL PROTEIN LACK
}

\author{
H. P. KOPYLCHUK, I. M. NYKOLAICHUK \\ Institute of Biology, Chemistry and Bioresourses, \\ Yuriy Fedkovych Chernivtsi National University, \\ Ukraine, 58012, Chernivtsi, Kotsiubynsky 2 Str. \\ e-mail: g.kopilchuk@chnu.edu.ua
}

\begin{abstract}
The article is devoted to the study of the main components of the glutathione system under conditions of toxic damage against the background of nutritional protein deficiency: the content of reduced and oxidized glutathione with the determination of the GSH/GSSG ratio, the activity of glutathione-dependent enzymes - glutathione peroxidase, glutathione transferase, glutathione reductase, and glucose-6-phosphate dehydrogenase. The concentration of reduced glutathione in the erythrocyte hemolysate was studied using Elman's reagent after deproteinization of the samples. Glutathione transferase activity was determined by the rate of formation of glutathione $S$ conjugates by reacting reduced glutathione with a substrate of 1-chloro-2.4-dinitrobenzene. Glutathione peroxidase activity was evaluated by the formation of oxidized glutathione. The activity of glutathione reductase in erythrocytes was determined by the method, is based on measuring the oxidation rate of $\mathrm{NADPH}+\mathrm{H}^{+}$, which is recorded by decreasing absorption at a wavelength of $340 \mathrm{~nm} . \mathrm{A}$ decrease in the ratio of GSH/GSSG in rat erythrocytes under conditions of toxic damage against a nutritional deficiency of protein is indicated by a functional shift in the thiol-disulfide balance towards increased use of the reduced form of glutathione for antioxidant protection. It was established that toxic damage is a key factor in reducing the level of glutathione transferase against the background of an increase in glutathione peroxidase activity in rat erythrocytes, the activation of which probably prevents the progression of LPO processes. At the same time, under conditions of toxic damage, against the background of alimentary protein deficiency, a decrease in glutathione reductase and glucose-6phosphate dehydrogenase activity is observed, which leads to blocking of the first stage of glucose-6-phosphate metabolism in the pentose phosphate cycle, resulting in a decrease in the amount of NADPH and, accordingly reduced glutathione.
\end{abstract}

Keywords: glutathione, glutathione transferase, glutathione peroxidase, glutathione reductase, glucose-6-phosphate dehydrogenase, erythrocytes.

Introduction. Recently, against the background of an unbalanced diet by nutrients, the occurrence of acute and chronic diseases is increasingly being observed, caused by damage to body cells by various poisons, drugs, chemicals, radiation and the like. The development of the manifestations of these diseases depends on the adaptive capabilities of the functioning of numerous biochemical systems of the body (Semba, 2016; Grover et al., 2009).

Any inflammatory process is accompanied by a disruption of the metabolic mechanisms of regulation of oxygen homeostasis in the cells. This leads to an increase in the production of reactive oxygen intermediate (ROI), depletion of the pool of bioantioxidants and an increase in local reactions of lipid peroxidation (LPO), which, in turn, can cause cell death (Holzerová et al., 2015; D'Autréaux et al., 2007; Hammond et al., 2011).

A significant oxygen content in erythrocytes determines the high rate of formation of superoxide anion radical $\left(\mathrm{O}_{2}^{-}\right)$, hydrogen peroxide $\left(\mathrm{H}_{2} \mathrm{O}_{2}\right)$ and hydroxyl radical $(\mathrm{OH})$, which are highly reactive and can be damaging to biomembrane proteins and lipids
(Fang et al., 2002). A non-enzymatic oxidation of hemoglobin to methemoglobin acts as a constant source of ROI in red blood cells. Therefore, red blood cells that constantly interact with oxygen contain effective antioxidant systems that can neutralize active oxygen metabolites (Cimen, 2008).

The glutathione redox system, which includes glutathione peroxidase (EC 1.11.1.9, GP), glutathione reductase (EC 1.8.1.7, GR), glutathione transferase (EC 2.5.1.18, GT) and reduced glutathione, $(\mathrm{GSH})$, is of particular importance in the antiradical and antiperoxidant protection of cells (Kalinina et al., 2014; Deponte, 2013).

The study of the glutathione system and its redox state (GSH/GSSG) occupies an important place in assessing the development of oxidative stress under various physiological conditions of the body and pathological processes (Kumar et al., 2011). So, today quite often studies of some redox pairs are carried out, in particular, GSH/GSSG (red blood cells), cysteine/cystine (blood plasma). Red blood cells that lack specialized organelles exhibit a redox potential of the GSH/GSSG pair that is close to other 
differentiated cells. That is why it is believed that the red blood cell oxidation potential of glutathione reflects the status of the antioxidant system of the whole organism (Giustarini et al., 2017).

Considering the above, the aim of this work was to study the major components of the glutathione system in rat erythrocytes under conditions of toxic damage against the background of alimentary protein deprivation.

Materials and methods. The studies were carried out on sexually mature white outbred rats of 2.5-3 months and 130-150 g in weight. Keeping, caring, labeling animals and all other manipulations were carried out in compliance with the provisions of the «European Convention for the Protection of Vertebrate Animals used for experimental and other scientific purposes» (Strasbourg, 1986) and the «General Ethical Principles of Animal Experiments» adopted by the Sixth National Congress of Bioethics (Kiev, 2016).

During the experiment, the rats were in standard plastic cages (no more than 3-4 individuals of the same sex in each) with pre-sterilized sand litter.

Animals were fed once a day in the morning with free access to food and water (diet - ad libitum). During the entire experiment, the animals were monitored. These parameters were subsequently used to normalize the daily diet, taking into account the principle of pair nutrition (Mashiko et al., 2007).

To reproduce the experimental acute toxic damage, the widespread method of administering acetaminophen per os to research animals at the rate of $1250 \mathrm{mg} / \mathrm{kg}$ of animal weight in the form of a suspension in $2 \%$ starch gel solution for 2 days was used (Stefanov, 2001).

The research model involved the division of animals into groups: I - animals that received a balanced semi-synthetic diet, control group (C) (Reeves et al., 1993); II - animals that consumed a semi-synthetic low protein diet (LPD) for 28 days (Kopylchuk et al., 2017); III - animals who, after staying on a balanced diet, were simulated toxic damage with acetaminophen (TD); IV - animals that were induced acute toxic damage with acetaminophen (LPD+TD) against the background of alimentary protein deprivation.

Cervical dislocation of research rats under light ether anesthesia was performed on days 28 and 31 of the experiment, observing the rules for the humane treatment of laboratory animals.

To obtain red blood cells, whole blood stabilized with a $5 \%$ sodium citrate solution was used. To obtain a hemolysate, the erythrocyte suspension washed with physiological solution was treated with chloroform (Kamyishnikov, 2004).

The concentration of reduced glutathione in the erythrocyte hemolysate was studied using Elman's reagent after deproteinization of the samples. The principle of the method is based on the interaction of 5.5'-dithiobis-2-nitrobenzoic acid with free $\mathrm{SH}$ groups of glutathione. As a result of this reaction, a colored product is formed - thionitrophenyl anion, the amount of which is directly proportional to the content of glutathione SH-groups (Beutler, 1990). The absorption of the test samples was measured on a CARY 60 spectrophotometer (USA) at a wavelength of $412 \mathrm{~nm}$.

To determine the content of oxidized glutathione in the reaction mixture, zinc dust was added in order to convert the oxidized form to the reduced one (Sedlak et al., 1968). Thus, the content of total glutathione (GSH+GSSG) was obtained. The concentration of the oxidized form of glutathione was determined by the difference in the content of total and reduced glutathione.

Glutathione transferase activity was determined by the rate of formation of glutathione $\mathrm{S}$ conjugates by reacting reduced glutathione with a substrate of 1chloro-2.4-dinitrobenzene (CDNB). The reaction mixture included: erythrocyte hemolysate, $0.1 \mathrm{M} \mathrm{Na}-$ phosphate buffer, $\mathrm{pH} 6.5,0.015 \mathrm{M}$ GSH solution, $0.015 \mathrm{M}$ CDNB solution. The absorption of the concentration of GSH-CDNB was measured at a wavelength of $340 \mathrm{~nm}$ (maximum absorption of glutathione-S-CDNB) in $0.5 ; 1.5 ; 2.5$ and $3.5 \mathrm{~min}$ (Habig et al., 1974).

Glutathione peroxidase activity was evaluated by the formation of oxidized glutathione (Vlasova et al., 1990). 0.3 M phosphate buffer, $\mathrm{pH} 7.4,12 \mathrm{mM}$ sodium azide solution, $6 \mathrm{mM}$ EDTA, $2.5 \mathrm{mM} \mathrm{GSH}$ solution and erythrocyte hemolysate were added to the reaction mixture. The reaction was initiated by the addition of $1.8 \mathrm{mM} \mathrm{H}_{2} \mathrm{O}_{2}$. The absorption of oxidized glutathione was determined at a wavelength of $260 \mathrm{~nm}$. The molar absorption coefficient of oxidized glutathione for recalculation of the enzyme activity was $5660 \mathrm{M}^{-1} \cdot \mathrm{cm}^{-1}$.

The activity of glutathione reductase in erythrocytes was determined by the method (Vlasova et al., 1990). The principle of the method is based on measuring the oxidation rate of $\mathrm{NADPH}+\mathrm{H}^{+}$, which is recorded by decreasing absorption at a wavelength of $340 \mathrm{~nm}$. To carry out this procedure, $100 \mu \mathrm{l}$ of erythrocyte hemolysates, $50 \mathrm{mM}$ potassium phosphate buffer, $\mathrm{pH}$ 7.0, containing $1 \mathrm{mM}$ EDTA, $0.5 \mathrm{mmol}$ of oxidized glutathione solution were added directly to the cuvette. By adding $100 \mu \mathrm{l}$ of a $0.1 \mathrm{mM} \mathrm{NADPH}+\mathrm{H}^{+}$solution, a glutathione reduction reaction was initiated. The change in absorbance was recorded at a wavelength of $340 \mathrm{~nm}$ after 1 minute for 3 minutes against a sample containing all components except oxidized glutathione. The molar absorption coefficient for the conversion of the enzyme activity was $6220 \mathrm{M}^{-1} \cdot \mathrm{cm}^{-1}$. 
The activity of glucose-6-phosphate dehydrogenase was studied by the method (Beutler, 1971). The reaction of the formation of $\mathrm{NADPH}+\mathrm{H}^{+}$is practically irreversible; therefore, the enzyme activity is determined by the rate of NADP reduction. The erythrocyte hemolysate was added to the reaction mixture containing $0.05 \mathrm{M}$ Tris- $\mathrm{HCl}$ buffer, $\mathrm{pH} 7.5$, $0.1 \mathrm{mM} \mathrm{MgSO}_{4}, 0.005 \mathrm{M}$ NADP at the rate of $300 \mu \mathrm{g}$ hemoglobin. The reaction was started by adding a 1.5 $\mathrm{mM}$ glucose-6-phosphate solution. Absorption was measured on a spectrophotometer after $30 \mathrm{~s}$ for $3 \mathrm{~min}$ at a wavelength of $340 \mathrm{~nm}$. The molar absorption coefficient for the conversion of the enzyme activity was $6220 \mathrm{M}^{-1} \cdot \mathrm{cm}^{-1}$.

The specific activity of the studied enzymes was expressed in $\mu \mathrm{mol} /(\min \times \mathrm{g} \mathrm{Hb})$.

The concentration of total hemoglobin was determined by the hemoglobin-cyanide method using the standard Filisit-Diagnostics reagent test kit (Ukraine).

Statistical analysis of the obtained research results was carried out using statistical analysis applications Microsoft Excel 2010. To assess the intergroup differences, the Student t-test was used. The difference between the indices was considered statistically significant at $\mathrm{p}<0.05$.

Results and Discussion. In the literature (Kulinsky et al., 2009; Kulinsky et al., 2009), in addition to the traditional concepts of the biochemical functions of GSH as a key antioxidant, cofactor in glutathione-dependent detoxification reactions, GSH participation in the deposition of cysteine, maintenance of microelement homeostasis, and the formation of the thiol component of the redox buffer of most differentiated cells, in particular erythrocytes, is considered (Nagy, 2013; Dalton et al., 2004).

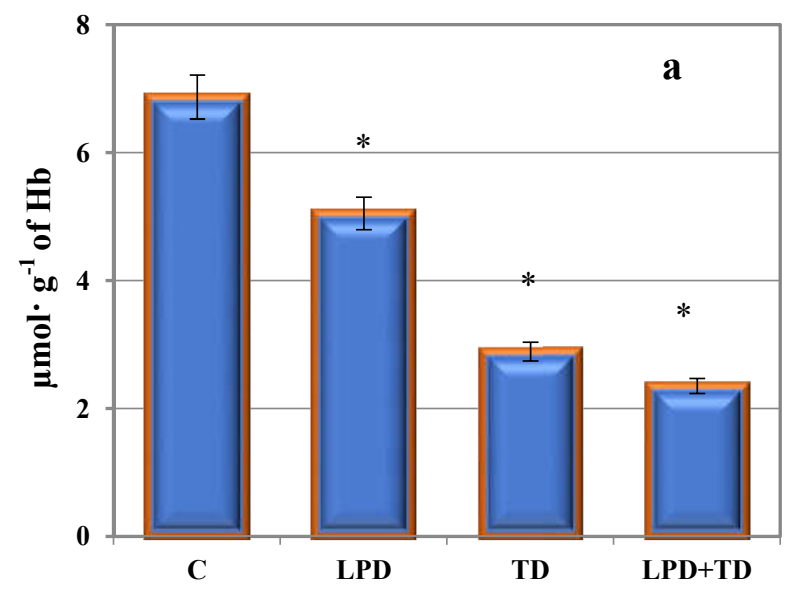

Approximately $99.5 \%$ of blood GSH is contained in red blood cells $(8.77 \mathrm{mmol} / \mathrm{g}$ hemoglobin or at a concentration of 2.73-3.50 mmol/l) (Jones et al., 2009). There is an idea of red blood cell GSH as a biomarker of the body's GSH status. This also applies to the redox of erythrocyte GSH, the range of which is similar to that in other differentiated cells and is identical for different types of cells (Buko et al., 2014).

The research results showed that in the erythrocyte hemolysate of all animal research groups, a decrease in the content of reduced glutathione is observed compared to the control values (Fig. 1, a). So, GSH maintains the essential thiol status of proteins and is a reservoir of cysteine, since this amino acid is extremely unstable under extracellular conditions and oxidizes very quickly to cystine in processes whose products are potentially toxic ROI (Kalinina et al., 2014). Under physiological conditions, the $\gamma$-glutamyl cycle allows the use of GSH as a continuous source of cysteine. Cysteine is transported to cells, where the bulk of it is spent on the synthesis of GSH, part of it is part of the proteins, depending on the needs of the cell, the remainder is degraded to sulfate and taurine.

In the literature (Rizvi et al., 2010) it is noted that the intake of L-cysteine in red blood cells depends on its concentration in blood plasma. Red blood cells absorb and transfer L-cysteine to peripheral tissues when its plasma content increases. Although three amino acids are required for the synthesis of GSH, the rate of synthesis of the tripeptide is determined only by the bioavailability of L-cysteine. Therefore, GSH deficiency in erythrocytes under conditions of nutritional protein deficiency (Fig. 1, a) is obviously due to a disruption of glutathione synthesis caused by a decrease in cysteine intake.

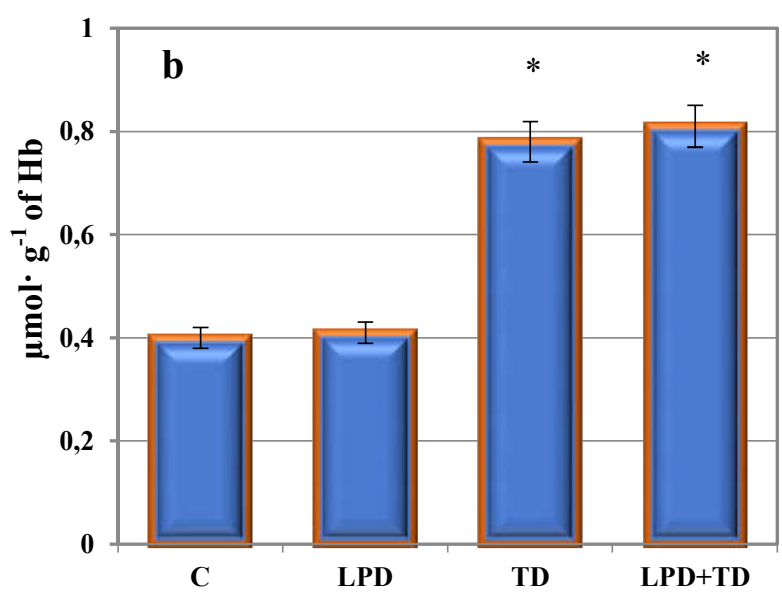

Fig. 1. The content of reduced (a) and oxidized (b) glutathione in rat erythrocytes under conditions of toxic damage against the background of nutritional protein deficiency

Note (hereinafter): $C$ - animals that received a full semi-synthetic diet; $L P D$ - animals that consumed a diet, where the protein content was 1/3 of the generally accepted norm; TD - animals that simulated acute toxic damage; LPD $+T D$ animals that were simulated toxic damage against the background of nutritional protein deficiency; ${ }^{*}-$ statistically significant difference compared with the control, $P \leq 0.05$. 
At the same time, a decrease in GSH content under conditions of toxic damage can be considered from two perspectives: firstly, this may be due to a decrease in GSH content in liver cells, which is confirmed by our previous studies (Kopylchuk et al., 2014), due to the formation of conjugates with a highly reactive metabolite of acetaminophen-N-acetylbenzoquinoneimine or due to the increased formation of a disulfide form of GSSG in red blood cells.

We found that changes in the GSSG content in erythrocyte hemolysate are observed only if toxic doses of acetaminophen are administered regardless of the diet and are almost twice as high as the control values (Fig. 1, b).

Recent scientific sources (Buko et al., 2014; Kulinsky et al., 2007) note that changes in the glutathione system in blood plasma occur as a result of inflammation and cytolysis of hepatocytes, while in erythrocytes they become reactions to oxidative stress. Red blood cells with a reduced GSH content are easily exposed to oxidative metabolites, which leads to precipitation of hemoglobin and its deposition in red blood cells in the form of Heinz bodies.

Oxidative stress can lead to a significant accumulation of GSSG in the liver and its release into the blood, followed by distribution between red blood cells and plasma (D'Autréaux et al., 2007). For example, an increased GSSG content in blood plasma can cause oxidation of thiol groups of plasma proteins and/or proteins of basolateral erythrocyte membranes and their inactivation. Therefore, the GSH/GSSG ratio is an important criterion for nonspecific resistance of the organism to oxidative stress (Deponte, 2013).

As for the ratio of GSH/GSSG in rat erythrocytes, its level decreases only with the introduction of toxic doses of acetaminophen regardless of the amount of food protein (Fig. 2). Analyzing our results, we can assume that the redox of erythrocyte glutathione will shift towards oxidation.

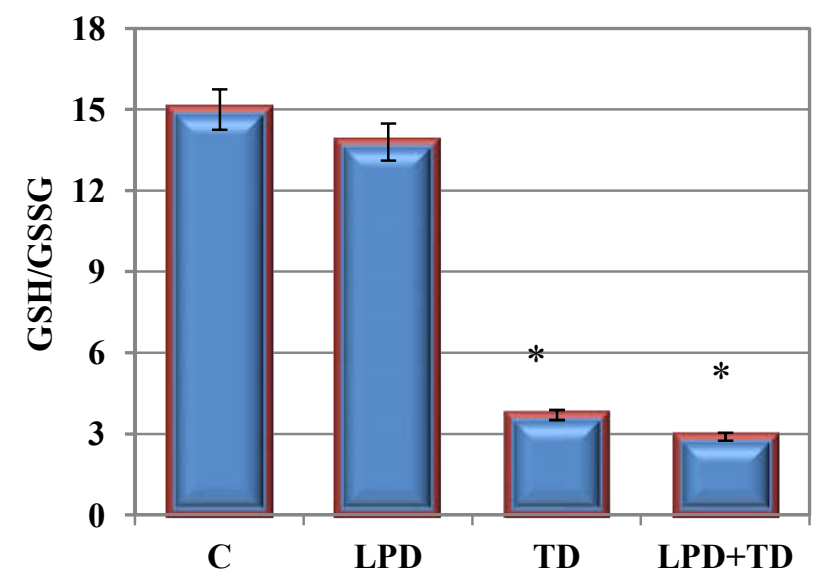

Fig. 2. The ratio of GSH/GSSG in rat erythrocytes under conditions of toxic damage against nutritional protein deficiency
A significant part of the biological functions of glutathione is carried out by converting reduced glutathione to the oxidized form using the enzyme glutathione peroxidase and subsequent return to GSH with the participation of NADPH-dependent glutathione reductase (Lushchak, 2012), which uses this cofactor from the pentose phosphate shunt (Kulinsky et al., 2009). That is why the GSH/GSSG ratio determines the oxidative status of cells and is clearly regulated by the two aforementioned enzymes.

We found that an increase in glutathione peroxidase activity in erythrocytes is observed only in groups of rats that were given toxic doses of acetaminophen, regardless of the enrichment of the diet with protein, compared with the control indices (Fig. 3, a).

In almost all cases, regardless of the etiology of the disease, a universal pathophysiological mechanism of damage associated with the formation of ROI and lipid peroxidation products is launched in the liver cells. Recent publications by a group of scientists confirm the intensification of free radical processes under the experimental conditions simulated by us (Kopylchuk et al., 2016). Glutathione peroxidase is considered one of the key enzymes in a coherent antioxidant defense system that maintains a constant level of free radical products. Glutathione peroxidase catalyzes the neutralization of hydrogen peroxide and lipid hydroperoxides formed in biological membranes under the action of active oxygen metabolites, without the formation of free radicals, using reduced glutathione as a hydrogen donor (Aashique et al., 2018).

An increase in the activity of glutathione peroxidase in animal erythrocytes is probably the physicochemical mechanism of a protective reaction of an adaptive organism to excessive ROI formation under these experimental conditions (Kopylchuk et al., 2016). Since NAPQI, arising in the process of acetaminophen metabolism, damages cell membranes and stimulates the formation of lipid hydroperoxides, it is obvious that this link of the enzymatic antioxidant system is aimed at neutralizing them (Deponte, 2013; Kulinsky, 2009).

Thus, the reaction of erythrocyte GSH is considered as a mechanism for the adaptation of the antioxidant defense of an organism to acute toxic damage or as an exhaustion of the resource of this defense in conditions of pronounced oxidative stress. It should be noted that, by metabolizing $\mathrm{ROOH}$, glutathione peroxidase can prevent the accumulation of secondary peroxidation products, but it cannot neutralize them, unlike glutathione transferase. 

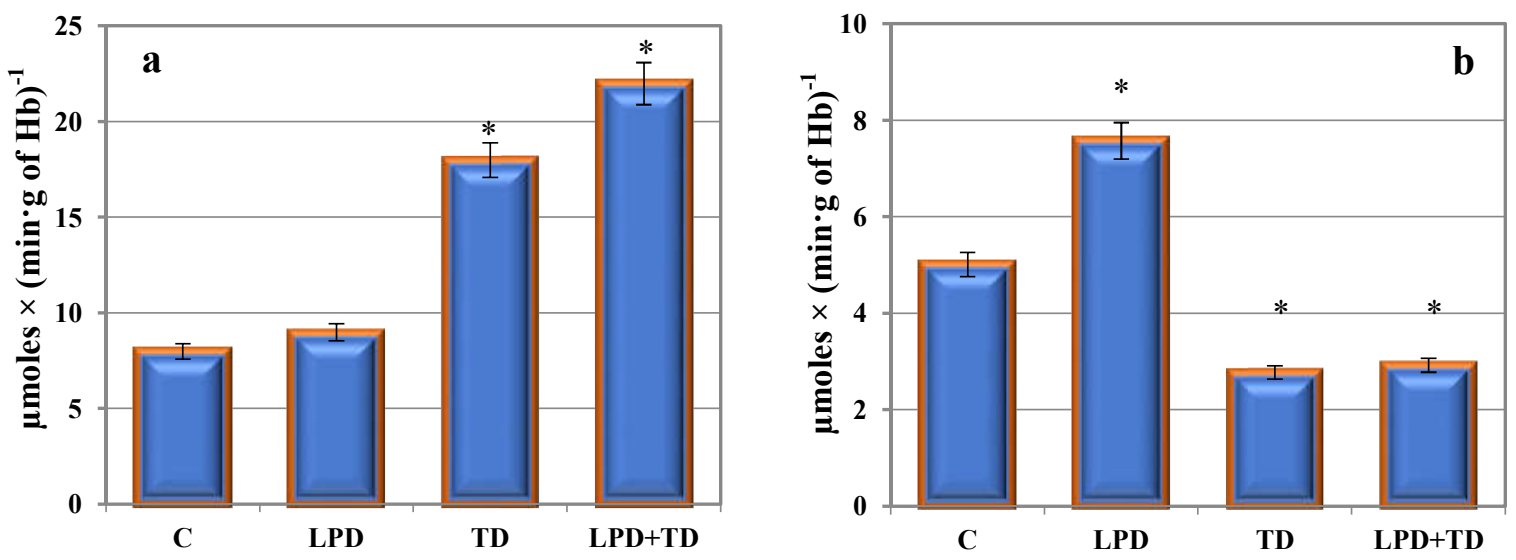

Fig. 3. The activity of glutathione peroxidase (a) and glutathione transferase (b) in rat erythrocytes under conditions of toxic damage against nutritional protein deficiency

Repeatedly in the literature (Kulinsky et al., 2009; Korzhov et al., 2007; Hayes et al., 2005) it is noted that along with glutathione peroxidase, the reduction of organic peroxides (hydroperoxides and endoperoxides) to alcohols with the participation of reduced glutathione occurs under the action of glutathione transferase. Due to the Se-independent glutathione peroxidase activity, glutathione transferase restores hydroperoxides of PUFAs, phospholipids, and cholesterol.

An analysis of the results of studies of the functioning of glutathione transferase indicates multidirectional changes in the activity of the studied enzyme in rat erythrocytes, which are manifested by the activation of glutathione transferase under conditions of nutritional protein deficiency (1.5 times compared with the control) and the inhibition of its activity when the toxin enters the body (Fig. 3, b). In the first case, an increase in the activity of glutathione transferase in erythrocytes can be considered as a compensatory reaction in response to the development of stress-adaptive mechanisms of the body regarding protein deficiency or the accumulation of peroxidation products. At the same time, under conditions of acetaminophen-induced hepatotoxicity, a decrease in the activity of glutathione transferase is probably associated with a suppression of its detoxification function.

The glutathione system is considered a natural cytoprotective system in acute intoxication. The direction, severity and duration of a change in the state of the glutathione system during acute xenobiotic poisoning is determined by the amount of the administered dose of the toxin, its toxico-kinetic and toxic-dynamic parameters (distribution in the body and predominant accumulation in tissues, features of metabolic transformations, the presence of specific mechanisms of toxic effects), tissue features of glutathione metabolism (Kumar et al., 2011).

So, in rat erythrocytes under conditions of the administration of toxic doses of acetaminophen against the background of nutritional protein deficiency, glutathione peroxidase is activated with a simultaneous decrease in glutathione transferase activity, where toxic damage is a key factor in the established changes.

In many reactions catalyzed by GP and GT, two GSH molecules are connected by a disulfide bond and form the so-called oxidized glutathione. For restoration of GSSG in liver cells and, consequently, GSH recycling in cells, a conjugated NADPHglutathione reductase system exists (Couto et al., 2016). The main biological significance of this enzyme is to maintain a stably high level of reduced glutathione in the cells.

In this regard, the next stage of the work was the study of the activity of glutathione reductase in rat erythrocytes to establish an unambiguous answer about the reduction in the content of reduced glutathione, which can be associated either with the active use of the reduced form in transferase and peroxidase reactions, or with insufficient restoration of the oxidized form of GR.

We found significant changes in the activity of glutathione reductase in the hemolysate of rat erythrocytes as compared with the control indices only under conditions of modeling acetaminopheninduced damage regardless of the amount of protein entering the body (Fig. 4, a). A decrease in GR activity against the background of an increase in the content of oxidized glutathione (Fig. 1, b), which is used by the enzyme as a substrate, indicates a direct dependence of the established functional changes on the intake of NADPH. 

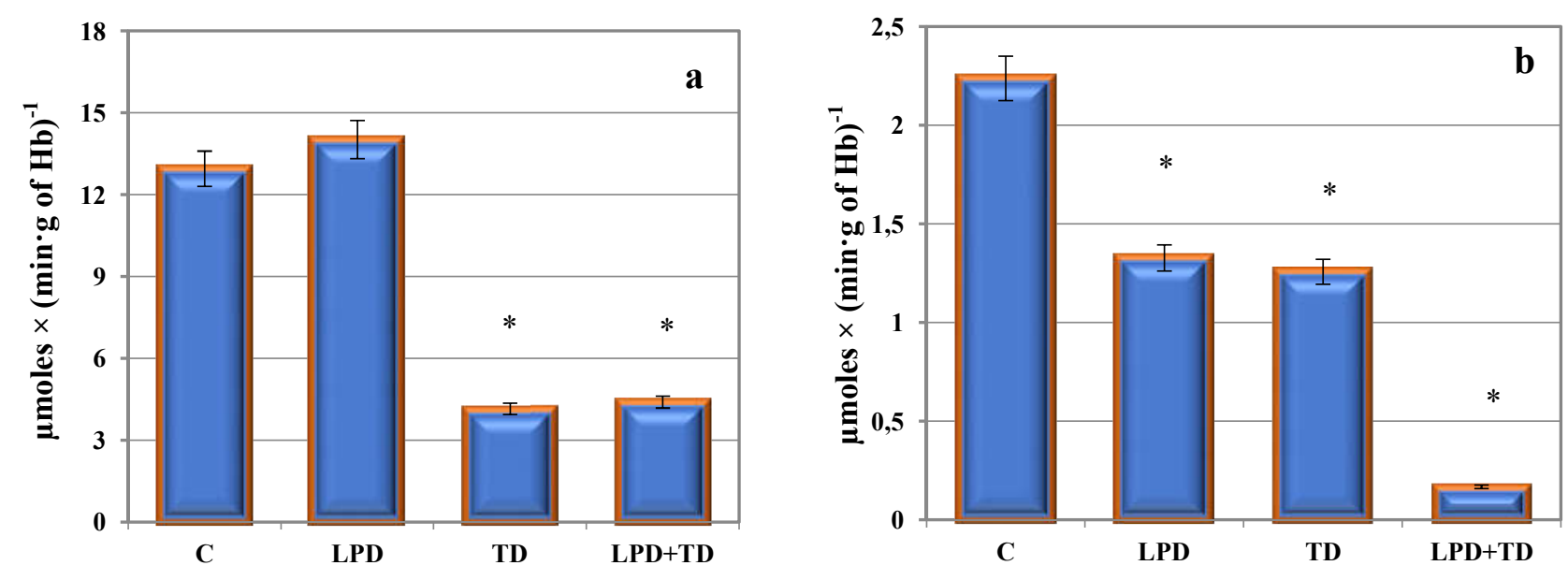

Fig. 4. The activity of glutathione reductase (a) and glucose-6-phosphate dehydrogenase (b) in rat erythrocytes under conditions of toxic damage against nutritional protein deficiency

The body's need for NADPH is about $50 \%$ covered by the pentose phosphate cycle, since $\mathrm{NADP}^{+}$is restored in the glucose-6-phosphate dehydrogenase reaction. It is this reaction that provides red blood cells with the necessary amount of NADPH, the most important hydrogen donor used to restore glutathione. Rapid glutathione regeneration protects hemoglobin from oxidative denaturation (Gavriliuc et al., 2011).

It was established that in all experimental groups of rats, a decrease in glucose-6-phosphate dehydrogenase activity was observed compared with the control indices (Fig. 4, b) with low values of the studied enzymatic activity under conditions of modeling acute toxic damage against the background of nutritional protein deficiency. Such changes are uniquely due to a combination of two factors negative for the body.

Thus, with a deficiency of glucose-6-phosphate dehydrogenase, the concentration of NADPH decreases, which is a prerequisite for a decrease in the content of reduced glutathione. The lack of GSH in red blood cells is accompanied by an increase in the concentration of methemoglobin and increased oxidation of membrane proteins. The key mechanism is loss of phospholipid distribution or externalization of phosphatidylserine from the erythrocyte membrane (Van Wijk et al., 2005). In the case of the oxidation of $\mathrm{SH}$ groups of hemoglobin molecules, the formation of cross disulfide bonds occurs, which leads to aggregation of hemoglobin protomers with the formation of Heinz bodies (Stantont, 2012).

Conclusions. So, under conditions of toxic damage, against the background of nutritional protein deficiency, a decrease in glutathione reductase and glucose-6-phosphate dehydrogenase activity is observed, which leads to blocking the first stage of glucose-6-phosphate metabolism in the pentose phosphate cycle, resulting in a decrease in the amount of NADPH and, accordingly, reduced glutathione.

\section{References:}

1. Aashique M., Roy A., Diamond A., Bera S. Subcellular compartmentalization of glutathione peroxidase 1 allelic isoforms differentially impact parameters of energy metabolism. $J$ Cell Biochem. 2018. doi: 10.1002/jcb.27610.

2. Beutler E. Red cell metabolism a manual of biochemical methods. Orlando: Grune \& Stration, 1990. 131-134.

3. Beutler E. Red Cell Metabolism. New York: Grune \& Stratton, 1971. 62-64.

4. Buko I.V., Polonetsky L.Z., Mrochek A.G., Moiseenok A.G. Antioxidant status and glutathione redox potential of erythrocytes in patients with acute coronary syndrome. Ukr. Biochem. J. 2014; 86(3): 114-124.

doi: http://dx.doi.org/10.15407/ubj86.03.114. (In Russian).

5. Cimen M.Y. Free radical metabolism in human erythrocytes. Clin Chim Acta. 2008; 390(1-2): 1-11. DOI: 10.1016/j.cca.2007.12.025.

6. Couto N., Wood J., Barber J. The role of glutathione reductase and related enzymes on cellular redox homoeostasis network. Free Radic Biol Med. 2016; 95: $\quad P$. 27-42. 10.1016/j.freeradbiomed.2016.02.028.

7. Dalton T.P., Chen Y., Schneider S.N., Nebert D.W., Shertzer H.G. Genetically altered mice to evaluate glutathione homeostasis in health and disease. Free Radic Biol Med. 2004; 37(10): 1511-1526. DOI: 10.1016/j.freeradbiomed.2004.06.040.

8. D'Autréaux B., Toledano M.B. ROS as signalling molecules: mechanisms that generate specificity in ROS homeostasis. Nat Rev Mol Cell Biol. 2007; 8(10): 813-824. DOI: $10.1038 / \mathrm{nrm} 2256$.

9. Deponte M. Glutathione catalysis and the reaction mechanisms of glutathione-dependent enzymes. Biochim Biophys Acta. 2013; 1830(5): 3217-3266. DOI: $10.1016 /$ j.bbagen.2012.09.018. 
10. Fang Y.Z., Yang S., Wu G. Free radicals, antioxidants, and nutrition. Nutrition. 2002; 18(10): 872-879. DOI: 10.1016/s0899-9007(02)00916-4.

11. Gavriliuc L.A., Corcimaru I.F., Robu M.V., Lisii L.T. Glutathione-dependent enzymes and glucose-6phosphate dehydrogenase of blood in patients with lymphosarcoma (non-hodgkin's disease). Biomeditsinskaya Khimiya. 2011. T. 57(2): C. 225231. (In Russian).

12. Giustarini D., Colombo G., Garavaglia M.L., Astori E., Portinaro N.M., Reggiani F., Badalamenti S., Aloisi A.M., Santucci A., Rossi R., Milzani A., DalleDonne I. Assessment of glutathione/glutathione disulphide ratio and S-glutathionylated proteins in human blood, solid tissues, and cultured cells. Free Radic Biol Med. 2017; 112: 360-375. DOI: 10.1016/j.freeradbiomed.2017.08.008.

13. Grover Z., Ee L.C. Protein energy malnutrition. Pediatr Clin North Am. 2009; 56(5): 1055-1068. DOI: 10.1016/j.pcl.2009.07.001.

14. Hammond E.G., White P.J. A Brief History of Lipid Oxidation. Journal of the American Oil Chemists Society. 2011; 88(7): 891-897. DOI: 10.1007/s11746011-1761-8.

15. Hayes J.D., Flanagan J.U., Jowsey I.R. Glutathione transferases. Annual Review of Pharmacology and Toxicology. 2005; 45: 51-88. DOI: 10.1146/annurev.pharmtox.45.120403.095857.

16. Holzerová E., Prokisch H. Mitochondria: Much ado about nothing? How dangerous is reactive oxygen species production? Int J Biochem Cell Biol. 2015; 63: 16-20. DOI: 10.1016/j.biocel.2015.01.021.

17. Jones D.P., Liang Y. Measuring the poise of thiol/disulfide couples in vivo. Free Radic Biol Med. 2009; 47(10): 1329-1338. DOI: 10.1016/j.freeradbiomed.2009.08.021.

18. Kalinina E.V., Chernov N.N., Novichkova M.D. The role of glutathione, glutathione transferase and glutaredoxin in the regulation of redox-dependent processes. Uspehi biologicheskoy himii. 2014; 54: 299-348. DOI: 10.1134/S0006297914130082. (In Russian).

19. Kamyishnikov V.C. Manual for clinical and biochemical research and laboratory diagnostics. M.: Medpressinform, 2004. 414 c. (In Russian).

20. Kopylchuk G.P., Voloshchuk O.M. Peculiarities of the free radical processes in rat liver mitochondria under toxic hepatitis on the background of alimentary protein deficiency. Ukr. Biochem. J. 2016; 88(2): 6672. DOI: $10.15407 / \mathrm{ubj} 88.02 .066$.

21. Kopylchuk H.P., Nykolaichuk I.M., Zhuretska O.M. Rat liver arginase system under acetaminophen-induced toxic injury and protein deprivation. Ukr. Biochem. J. 2017; 89(2): 92-98. doi: https://doi.org/10.15407/ubj89.02.092.

22. Kopylchuk H.P., Buchkovska I.M. The state of the glutathione system of liver cells of rats for low-protein diet and acute hepatotoxic injury. Ukr. Biochem. J. 2014; 86(5 Suppl 1): 165-166. (In Ukrainian).

23. Korzhov V.I., Zhadan V.N., Korzhov M.V. The role of the glutathione system in the processes of detoxification and antioxidant protection. Zhurnal AMN Ukraina. 2007; 13(1): 3-19. (In Russian).
24. Kulinsky V.I., Kolesnichenko L.S. Glutathione system I. Synthesis, transport, glutathione transferases, glutathione peroxidases. Biomeditsinskaya Khimiya. 2009; 55(3): 255-277. (In Russian).

25. Kulinsky V.I., Kolesnichenko L.S. Glutathione system. II. Other enzymes, thiol-disulphide metabolism, inflammation and immunity, functions. Biomeditsinskaya Khimiya. 2009; 55(4): 365-379. (In Russian).

26. Kulinsky V.I., Leonova Z.A., Kolesnichenko L.S., Malov I.V., Danilov Yu.A. Glutathione system in erythrocytes and blood plasma in viral hepatites. Biomeditsinskaya Khimiya. 2007; 53(1): 91-98. (In Russian).

27. Kumar C., Igbaria A., D'Autreaux B., Planson A.G., Junot C., Godat E., Bachhawat A.K., DelaunayMoisan A., Toledano M.B. Glutathione revisited: a vital function in iron metabolism and ancillary role in thiol-redox control. EMBO J. 2011; 30(10): 20442056. DOI: 10.1038/emboj.2011.105.

28. Lushchak V.I. Glutathione homeostasis and functions: potential targets for medical interventions. J Amino Acids. 2012; Article ID 736837: 26 pages, doi:10.1155/2012/736837.

29. Mashiko S., Ishihara A., Iwaasa H., Sano H., Ito J., Gomori A., Oda Z., Moriya R., Matsushita H., Jitsuoka M., Okamoto O., MacNeil D. J., Van der Ploeg L. H., Fukami T., Kanatani A. A pair-feeding study reveals that a Y5 antagonist causes weight loss in diet-induced obese mice by modulating food intake and energy expenditure. Mol Pharmacol. 2007; 71(2): 602-608. DOI: 10.1124/mol.106.029991.

30. Nagy P. Kinetics and mechanisms of thiol-disulfide exchange covering direct substitution and thiol oxidation-mediated pathways. Antioxidants \& Redox Signaling. 2013;18: 1623-1641. DOI: 10.1089/ars.2012.4973.

31. Reeves P.G., Nielsen F.H., Fahey G.C. Jr. AIN-93 purified diets for laboratory rodents: final report of the American Institute of Nutrition ad hoc writing committee on the reformulation of the AIN-76A rodent diet. J Nutr. 1993; 123(11): 1939-1951. DOI: 10.1093/jn/123.11.1939.

32. Rizvi S.I., Srivastava N. L-cysteine influx in diabetic erythrocytes. Biomeditsinskaya Khimiya. 2010; 56(5): 545-551. DOI: 10.18097/pbmc20105605545. (In Russian).

33. Sedlak J., Lindsay R.H. Estimation of total, proteinbound, and nonprotein sulfhydryl groups in tissue with Ellman's reagent. Anal Biochem. 1968; 25(1): 192205.

34. Semba R.D. The Rise and Fall of Protein Malnutrition in Global Health. Ann Nutr Metab. 2016; 69(2): 7988. DOI: $10.1159 / 000449175$.

35. Stantont R. C. Glucose-6-phosphate dehydrogenase, NADPH, and cell survival. IUBMB Life. 2012; 64(5): 362-369. DOI: 10.1002/iub.1017.

36. Stefanov O.V. Preclinical studies of drugs. Kyiv: Avicenna, 2001. 527 s. (In Ukrainian).

37. Van Wijk R., van Solinge W.W. The energy-less red blood cell is lost: erythrocyte enzyme abnormalities of glycolysis. Blood. 2005; 106(13): 4034-4042. DOI: 10.1182/blood-2005-04-1622. 
38. Vlasova S.N., Shabunina E.I., Pereslegina I.A. The activity of glutathione-dependent erythrocyte enzymes in children with chronic diseases. Laboratory work. 1990; 8: 19-21. (In Russian).
39. Habig W.H., Pabst M.J., Jakoby W.B. Glutathione-Stransferases. The first enzymatic step in mercapturic acid formation. J Biol Chem. 1974; 249(22): 71307139 .

\title{
ОСНОВНІ КОМПОНЕНТИ ГЛУТАТІОНОВОЇ СИСТЕМИ В ЕРИТРОЦИТАХ ЩУРІВ ЗА УМОВ ТОКСИЧНОГО УРАЖЕННЯ НА ТЛІ АЛІМЕНТАРНОЇ НЕСТАЧІ ПРОТЕЇНУ
}

\author{
Г. П. Копильчук, І. М. Николайчук
}

Робота присвячена дослідженню основних компонентів глутатіонової системи за умов токсичного ураження на тлі аліментарної нестачі протеїну: вмісту відновленого та окисленого глутатіону з визначенням співвідношення GSH/GSSG, активностей глутатіонозалежних ензимів - глутатіонпероксидази, глутатіонтрансферази, глутатіонредуктази, а також глюкозо-6-фосфатдегідрогеназної активності в еритроцитах щурів. Модель дослідження передбачала поділ тварин на групи: I - тварини, які отримували збалансований напівсинтетичний рачіон - група контролю; II - тварини, які протягом 28 діб споживали напівсинтетичний низькопротеїновий раціон; III - тварини, яким після перебування на збалансованому раціоні, моделювали токсичне ураження ацетамінофеном; IV - тварини, яким на тлі аліментарної депривації протеїну індукували гостре токсичне ураження ацетамінофеном. Концентрацію відновленого глутатіону в гемолізаті еритроцитів досліджували за допомогою реактиву Елмана після депротеїнізації зразків. Принции методу грунтується на взаємодії 5,5'-дитіобіс-2-нітробензойної кислоти з вільними SН-групами глутатіону. Для визначення вмісту окисленого глутатіону до реакційної сумімі вносили цинковий пил з метою переведення окисленої форми у відновлену. Глутатіонтрансферазну активність визначали за швидкістю утворення глутатіон-S-кон 'югатів шляхом взаємодї відновленого глутатіону із субстратом 1-хлор-2,4-динітробензолом. Активність глутатіонпероксидази оцінювали за утворенням окисленого глутатіону. Активність глутатіонредуктази в еритроцитах визначали шляхом вимірювання швидкості окислення $N A D P H+H^{+}$, щุo реєструється за зменшенням абсорбиії при довжині хвилі 340 нм. Зменшення співвідношення GSH/GSSG в еритроцитах щурів за умов токсичного ураження на тлі аліментарної нестачі протеїну засвідчує функиіональний зсув тіол-дисульфідного балансу в бік підвищеного використання відновленої форми глутатіону для антиоксидантного захисту. Встановлено, щзо токсичне ураження виступає ключовим чинником зниження рівня глутатіонтрансферази на тлі підвищення глутатіонпероксидазної активності в еритроцитах щурів, активація якої, вірогідно, запобігає прогресуванню процесів пероксидації ліпідів. Водночас за умов токсичного ураження на тлі аліментарної білкової недостатності спостерігається зниження глутатіонредуктазної та глюкозо-6-фосфатдегідрогеназної активностей, щзо зумовлює блокування першого етапу обміну глюкозо-6-фосфату в пентозофосфатному ичиклі, внаслідок чого зменшується кількість NADPH та, відповідно, відновленого глутатіону.

Ключові слова: глутатіон, глутатіонтрансфераза, глутатіонпероксидаза, глутатіонредуктаза, глюкозо-6фосфатдегідрогеназа.

Отримано редколегією 02.03.2020 